\title{
Consultation in Special Needs Education in Rural Schools in Sweden - An Act of Collaboration between Educators
}

\author{
Gerd Pettersson (Corresponding Author) \\ Department of Education, Umeå University. SE-90187 Umeå \\ Email: gerd.pettersson@umu.se Tel: 4690-786-9402
}

\author{
Kristina Ström \\ Faculty of Education and Welfare Studies at Åbo Akademi University \\ Vasa. PB 311 FI- 65101 VASA \\ Email: kristina.strom@abo.fi Tel: 358-6-3247300
}

Received: August 16, $2016 \quad$ Accepted: August 23, $2016 \quad$ Published: December 08, 2016
doi:10.5296/jet.v4i1.10422
URL: http://dx.doi.org/10.5296/jet.v4i1.10422

\begin{abstract}
The article attempts to shed light on how the expertise of special educators can be utilized in classroom teachers' professional development at rural schools with a diverse student body. The study focused on the educational consultations that took place between the two types of professionals, namely the special educators and the classroom teachers, at three rural schools in three communities in northern Sweden. The special educators did not work at the schools. Rather, they worked at Community centers and ran the consultation with the aid of ICT or when they visited the schools. The multiple-case study describes and analyzes the a) context for consultation, b) how consultation is used to support the teachers, and c) the consultation strategies. The data collection methods were observations, interviews, and questionnaires. After the interviews were transcribed, the data were analyzed by thematic content analysis. The results show that the consultations were based on students' needs, but the consultations focused on the learning environment more than on individual shortcomings. The two professionals collaborated and shared their professional expertise across professional boundaries. This boundary-crossing professional collaboration seems to deepen the consultation between the two professionals and enable them to work together to create a learning environment that supports all pupils.
\end{abstract}

Keywords: class teacher, consulting strategies, educational consultation, professional development, special educator. 


\section{Introduction}

Access to high-quality primary education within the communities where children and their families live is regarded as a "trademark" of a welfare society (Lind \& Stjernström, 2015). However, in many countries, maintaining a comprehensive school network in rural areas has become increasingly challenging due to shrinking and aging populations, financial constraints, and a lack of human capital (Autti \& Hyry-Beihammer, 2014; Cedering, 2016; Dowling, 2009; Kearns, Lewis, McCreanor \& Witten, 2009; Schafft \& Youngblood Jackson, 2010). Such demographic, social, and economic changes affect rural communities and schools. The challenges rural schools face are related to personnel, competence, population structure, and organizational factors. Schools in remote areas in particular face difficulties attracting and retaining qualified teachers and specialist teachers, for example, special education teachers (Berry, Petrin, Gravelle, \& Farmer, 2011; Pettersson, Ström, \& Johansen, 2016). Furthermore, many rural schools constantly live under the threat of closure (Autti \& Hyry-Beihammer, 2014; Cedering, 2016; Egelund \& Laustsen, 2006; Karlberg-Granlund, 2011; Pettersson et al., 2016; Solstad, 2009).

Nevertheless, as long as rural areas are populated, rural schools exist. The importance of understanding the special characteristics of rural schools through research has been highlighted by several rural researchers (Bæck, 2015; Howley, 2004; Howley \& Howley, 2014; Pini, Carrington \& Adie, 2014). Understanding rural schools includes understanding the context, the community of which the rural school is part (Bæck, 2015; Dowling, 2009; Hargreaves, 2009; Howley, 2004; Monk, 2007).

Teachers who work in rural schools face different working conditions compared to teachers in urban schools. Although rural communities are diverse, most rural schools share common characteristics, such as geographic isolation, a low number of students and teachers, multi-grade classrooms, diverse learning needs among the student body, a lack of support staff, and scarce professional development opportunities (Dowling, 2009; Monk, 2007; Pettersson et al., 2016). Moreover, the work of rural teachers differs from the work of their urban colleagues. Teachers, especially those who work at small and remote rural schools, are obliged to handle many issues themselves, ranging from administration to behavior management and sometimes even conflicts with the surrounding community (Karlberg-Granlund, 2009; McHenry-Sorber \& Schafft, 2014). Educational challenges caused by different learning needs among students combined with a lack of special educators may also place added strain on teachers who work in rural areas (Pettersson et al., 2016; Tuters, 2015). When a special educator is not available on a daily basis and a teacher has few, if any, colleagues to ask for advice, the situation can be especially challenging (Kuhl, Pagliano \& Boon, 2014). Research findings indicate that collaboration and work-related support are crucial for job satisfaction and teacher retention in rural areas (Barley \& Beesly, 2007; Berry, 2012; Malloy \& Allen, 2007). Although teacher support in matters related to special education seems to be important, the area is under-researched in rural research. Also Tuters (2015) points out that special education in rural schools is an uncommon theme in research. 
In order to fill this research gap we focus in this article on one work-related support strategy for teachers, school consultation. We describe and analyze consultation in the context of special education in small rural schools in Sweden. Our article attempts to shed light on how the expertise of special educators can be utilized in order to support the professional development of teachers who work in rural schools with a diverse student body. Student diversity is in this article conceptualized as the normal variation of students in a school, ranging from students with special educational needs (SEN) to gifted and talented students. However, our main interest is directed towards students with special educational needs.

To meet this end, we have formulated the following research questions: (1) How do teachers describe the rural school as a context for consultation? (2) How is consultation perceived as a teacher support strategy in rural schools? (3) What strategies in consultation between teachers and special educators appear?

\section{Literature Review}

\subsection{Rural Schools in Rural Areas}

Rural areas and rural schools are characterized by geographical, demographical and societal diversity, which should be taken into account in rural research (Bæck, 2015; Monk, 2007). At the same time, researchers interested in rural issues point out the importance of context or "sense of place," as Howley and Howley (2014, p. 7) conceptualize the relationship between the local rural community and education. Findings indicate that when a rural school is perceived as a valuable part of the surrounding community and the local culture, a unique learning environment where the teachers play a crucial role is created (Barley \& Beesly, 2007; Howley \& Howley, 2014). Similar results have been found in the Nordic context (Kalaoja \& Pietarinen, 2009; Karlberg-Granlund, 2009; Solstad, 2009). Close relationships between the school and the rural community promote a sense of belonging and participation (Autti \& Hyry-Beihammer, 2014; Bagley \& Hillyard, 2011; Kalaoja \& Pietarinen, 2009; Woods, 2006).

However, study findings also point in the opposite direction. When conflicts appear in the community, the close relationships can negatively affect the community-school relationship (Karlberg-Granlund, 2009; Mc Henry-Sorber \& Shafft, 2014). Several researchers (i.e., Bagley \& Hillyard, 2011; Hargreaves, Kvalsund, \& Galton, 2009; Murdoch, Lowe, Ward, \& Marsden, 2003) argue that it should not be assumed that just because a group of parents live in the same area a strong and positive relationship always exists between the community and the rural school. Another factor that can challenge the relationship in a negative way is the constant concern about the future of the rural school and the school's alleged inability to meet high-quality standards (Lind \& Stjernström, 2015; Pettersson et al., 2016; Woods, 2006), although there is no evidence, at least not in a Nordic context, that rural schools are inferior when it comes to student performance and learning outcomes (Åberg-Bengtsson, 2009; Solstad, 2009).

However, rural schools have characteristics that make the learning and teaching environment different compared to urban schools. The difference is related to contextual and structural 
factors but also to factors related to the teachers' work. The number of students is low, and multi-grade classrooms are common. The small student groups and the fact that the teachers often live in the rural communities allow close, familiar, and caring relationships between teachers and students (Pettersson et al., 2016; Tuters, 2015). School-community collaboration is also facilitated by the perception that the rural school is the heart of the village (Autti \& Hyry-Beihammer, 2015). However, rural schools are vulnerable learning environments due to geographical isolation, few young families moving in, organizational challenges, and long distances to public services (Karlberg-Granlund, 2009; Solstad, 2009; Woods, 2006). The distance factor is especially challenging when it comes to special educational support. Several studies have shown that teachers experience teaching in rural schools as challenging if the teachers do not have regular access to support services (Pettersson et al., 2016; Tuters, 2015). The work of rural teachers is complex and versatile, including administration, planning, curriculum adaptation, behavior management, and sometimes even conflict management in the surrounding community (Karlberg-Granlund, 2009; McHenry-Sober \& Schafft, 2014). Rural schools are in general characterized by student diversity, which increases the complexity of the rural teachers' work. Student diversity can contribute to creative pedagogical solutions that suit all the students in the school (Pettersson et al., 2016). However, although the rural teachers in Pettersson et al.'s study had found ways to cope with the situation they wanted support in matters related to SEN on a regular basis, preferably consultation provided by the municipality's special educators.

\subsection{Consultation as a Teacher Support Strategy}

Regular and meaningful support seems to promote retention as well as resiliency among teachers who work in rural and other high-needs areas (Castro, Kelly \& Shih, 2010; Malloy \& Allen, 2007). In addition, professional collaboration, collegiality, and supportive teacher relationships have been identified as resiliency-building factors in rural and remote schools (Jarzabkowski, 2003). In a case study of a resiliency-building rural school, Malloy and Allen (2007) discussed the resiliency-promoting factors, caring and support, found in the study in relation to the four dimensions of collaboration (supportive, facilitative, informative, and prescriptive) identified by Pugach and Johnson (1995). Malloy and Allen (2007) characterized the supportive collaboration as caring about each other in various ways in a family-like atmosphere. The facilitative dimension of collaboration was visible, for instance, in team-teaching and reflective discussions. Sharing best practices between colleagues promoted professional capacity building. Standard mentoring programs and information-sharing networks were examples of informative collaboration that helped the teachers in the studied school handle various individual learning needs among the students. Prescriptive collaboration was the least prominent resiliency-building factor identified at the school, although this factor was present because of state-mandated accountability programs.

The goal of facilitative and informative collaboration is to enable teachers to grow in their professional roles and to become better at independently handling professional challenges (Malloy \& Allen, 2007; Pugach \& Johnson, 1995). Another support strategy that has the same goal is educational consultation. Educational consultation or school consultation is a 
wide field of different theoretical approaches and models (e.g., Erchul \& Sheridan, 2014). For the purpose of this study, we focus on educational consultation that takes place in the context of special education. Special education consultation is a form of indirect service delivery provided by a special educator that aims to support a classroom teacher who instructs diverse student groups (Idol, 2006; Sundqvist \& Ström, 2015).

Swedish special educators have a consulting role according to policy documents (Government Offices of Sweden, 2010, p. 800; National Agency for Education, general guidelines on working with additional adjustments, special support and action SKOLFS, 2014, p. 40). Consulting tasks include consultation to school personnel and school development in order to promote inclusion (Lindqvist, 2013; Sundqvist, von Ahlefeld Nisser, \& Ström, 2014). Although the policy documents do not specify the character of the consultation special educators are supposed to engage in, they are required to function as qualified dialogue partners and advisors to teacher colleagues, parents, professionals, and other stakeholders (Swedish code of statutes SFS, 2011, p. 186; von Ahlefeld Nisser, 2014). Swedish research on special educators' consulting tasks primarily view school consultation focused on special education issues as a consultee-centered activity where the consultee (e.g., classroom teacher) through reflecting discussions with the consultant (special educator) solves professional problems (Bladini, 2004; Sahlin, 2005). Direct advice focusing on individual students' learning challenges is given less emphasis in this approach. Reflection and advice, however, should be viewed as complementary, not mutually exclusive, approaches. However, to understand the nature of the special educator's consulting task, a third approach emphasizing collaboration should be considered. In a study of Finnish special education teachers as consultants, three main and sometimes overlapping types of consultation were found: consultation as counseling conversations (focus on advice), consultation as reflective conversations (focus on reflection), and consultation as cooperative conversations (focus on professional collaboration; Sundqvist \& Ström, 2015). In addition, von Ahlefeld Nisser (2009) identified a type of collaborative consultation strategy in which teachers meet in what she calls knowledge-creating dialogues. The idea behind the knowledge-creating dialogues and the cooperative conversations is that two teaching professionals, a special educator and a classroom teacher, meet to discuss and solve professional challenges together, emphasizing and using their own professional expertise (c.f. Sundqvist \& Ström, 2015; Sundqvist et al., 2014).

\subsection{Distributed Expertise}

In order to understand the nature of special education consultation in small rural schools, we used the concept distributed expertise. Distributed expertise is about professionals' ability to collaborate and to share their expertise with other professionals in order to promote problem solving and to expand existing knowledge (Edwards, Daniels, Gallagher, Leadbetter \& Warmington, 2009). According to Nowotny (2003), professional experts who work in interprofessional teams need to share expertise and expand their own knowledge base by integrating their existing professional knowledge with knowledge from other professional areas in order to successfully solve professional challenges. Distributed expertise, in other words, the ability to work across professional boundaries, calls for relational agency. 


\section{Macrothink}

Relational agency is a relational capacity that involves collaborative learning and problem solving (Edwards, 2005). Relational agency is about developing the ability to collaborate professionally and thus to promote the capacity to find common solutions to complex problems in collaboration with other professionals. According to Edwards (2005), this dynamic and capacity-building process can be categorized in two dynamic stages: a) to deepen the collaboration with others in order to expand the object of the activity or task in question and to develop an understanding of the capacity of the professional partner and $b$ ) to adjust one's own contribution in the professional dialogue in order to contribute to elaborated interpretations and answers that meet the partners' professional development needs. These stages expand and deepen the joint understanding of the problem or challenge in question. This professional exchange of knowledge and expertise requires professional competence, confidence, and recognition of other professionals' knowledge and sensitivity in collaborative situations (Edwards et al., 2009).

According to Edwards, Lunt, and Stamou (2010), relational agency is particularly relevant to the work of professionals who work alone without regular support of other professionals, in our case, teachers who work in rural schools without the support of special education expertise within a rural school.

\section{The Empirical Study}

\subsection{The Context of the Study}

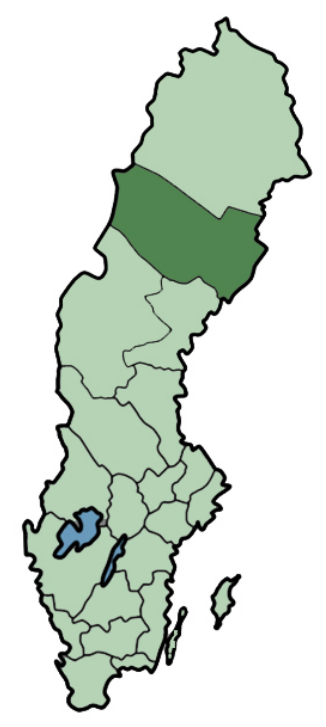

Figure 1. Västerbotten County. Location of the study

The context of the study is the county of Västerbotten in Sweden (Figure 1). The county, which includes 15 municipalities, is more sparsely populated than most other counties in the country. The county's total population is about 255,000 inhabitants. The majority (almost $80 \%$ ) of the county's population live in the coastal area, mainly in two medium-sized towns. Inland, there is one small town, but most of the inland region is dominated by rural areas with 
small villages. The majority $(80 \%)$ of the county's population lives in densely populated areas, which constitute about $30 \%$ of the total area of the county, while the remaining percentage $(20 \%)$ of the population inhabits $70 \%$ of the total area (County Administrative Board, 2015). This uneven population distribution makes Västerbotten a county with urban, sparsely populated, and very sparsely populated areas.

\subsection{Selection and Participants}

The multiple-case study reported in the present article was conducted in three rural schools in three rural municipalities in the county of Västerbotten in 2015. The chosen municipalities, located in the densely populated coastal region, in the rural inland area, and in the sparsely populated mountain areas were representative of the county's geographic and demographic structure. The selection process for the schools in these three areas was performed in several steps. Following the selection criteria from an earlier study (Pettersson et al., 2016), a rural school was defined as a school located in a rural area that has no more than 55 enrolled students and a handful (fewer than eight) of teachers teaching students or student groups of different ages and grades in the same classroom (multi-grade teaching). ${ }^{1}$ In a recent survey study, Pettersson and Näsström (submitted, 2015) identified 16 rural schools in the county of Västerbotten. In search of representative rural schools from the coastal region, from the rural inland area, and from the sparsely populated and remote mountain area, a statistical analysis of certain background variables (number of students, number of teachers, and distance from the municipality center) from the study by Pettersson and Näsström was conducted. Thus, three rural schools representing the variety of rural schools in the county were identified: two typical schools (around the median value of the variables) and one small and remote school (around the 5th percentile of the variables). Information about the special educators responsible for consultation in the selected schools was also obtained from the principals who participated in Pettersson and Näsström's study. The names of the participants are pseudonyms in order to protect the identity of the informants.

School A - The Coastal School is located in a small village on the outskirts of a medium-sized municipality with about 70,000 inhabitants. The village where the school is located has about 300 inhabitants. The travel time between the municipality center and the rural school is about 20 minutes by car. The school has four teachers and 46 students in grades 1-5. The students are divided into three classes (grade 1, grades 2-3, and grades 4-5). Two students have a diagnosis, but several students at the school need special education support temporarily or continuously. The teachers have access to a special educator from the municipality. The interviewed classroom teacher Anna has eight years of work experience, and the special educator Fanny has three years of work experience (as a special educator).

School B - The Inland School is located in a small municipality with about 4,000 inhabitants. The village where the school is located has about 350 inhabitants. The travel time between the municipality center and the rural school is about 45 minutes by car. The school has many students with a refugee or immigrant background who do not speak Swedish as

\footnotetext{
${ }^{1}$ There is no common, specifically Swedish definition of a rural area or rural school. Authorities and organizations in the three countries use different concepts and definitions for these two concepts.
} 
their native language. The school has five teachers and 38 students in grades $1-5$. The students are divided into two classes (grades 1-2 and grades 3-5). Two students have a diagnosis, but several students at school need special education support temporarily or continuously. The teachers have access to a special educator from the municipality. The interviewed classroom teacher Betty has 17 years of work experience, and the special educator Eve has 11 years of work experience (as a special educator).

School C - The Mountain School is located in a large and sparsely populated municipality with 2,500 inhabitants. The village where the school is located has about 80 inhabitants. The travel time between the municipality center and the rural school is about 90 minutes by car. The school has one teacher and one teaching assistant who does not have pedagogical training. The school has eight students in grades 1 to 5 . Two students have a diagnosis, and several students at the school need special education support temporarily or continuously. All students are taught together in one classroom. Some students are Sami (an indigenous population) and speak the Sami language. The school has access to a special educator from the municipality. The interviewed classroom teacher Carol, who also lives in the village, has 19 years of work experience, and the special educator Diana has 14 years of work experience (as a special educator).

After having identified the three schools, the researchers approached the schools' principals to invite the schools to participate in the study. The principals were also asked to suggest one classroom teacher for the study and to contact the special educator responsible for the school. The principals agreed and gave the necessary information, and all suggested informants agreed to participate in the study. From each of the three rural schools, one classroom teacher and one special educator participated in the study, for a total of six informants.

\section{Data Collection and Analysis}

The empirical data were collected in May 2015 during site visits to the schools. The data collection methods included observations, interviews, and questionnaires. During the school visits, the researchers observed authentic consultation sessions between the classroom teacher and the special educator. One session in each school was observed and recorded by digital recorders and recorded by using a digital video camera. The classroom teachers and the special educators were free to choose the content of the consultation and how they wanted to carry out the session. The only guideline the teachers had been given was that the observed consultation session should represent an authentic consultation session. The consultation sessions lasted from 80 to 120 minutes. Immediately after the sessions, the classroom teachers and the special educators were interviewed together in order to give them the opportunity to clarify and elaborate some aspects of the consultation, for instance, the purpose and content of consultation in general, previous and present consultation strategies, other activities related to consultation, access to other forms of support, school-community relationships, etc. The interviews were recorded on a digital recorder. Four days later, a questionnaire was sent to all six participants. The questionnaire contained background data of the schools, the number of teachers, the number of students, the surrounding and internal learning environment, etc. 
The collected data were processed and analyzed in several steps. The conversations from the three authentic consultation sessions were transcribed and resulted in 62 pages of text. The three interviews after the consulting sessions were transcribed into 53 pages. The background data from the questionnaires were categorized. The recordings from the digital video camera were not processed as data but used mainly for checking and validating interview data.

To understand the nature of special education consultation in rural schools, the data from the authentic consultation sessions and subsequent interviews were analyzed according to the principles of content analysis. The aim was to find stable categories that reflected the meaning of data in relation to the research questions (Graneheim \& Lundman, 2004). The data analysis was mainly inductive, but the theoretical framework and prior research constituted the lens through which the data for the three research questions were analyzed. The data analysis procedures were as follows: After the transcripts from the recorded consulting conversations and the interviews were read several times and the recordings were listened to, the categorization process began. As the amount of data was manageable, the data were categorized into different categories in two steps: a) first, manually by reading the transcripts and color-marking certain sentences and text passages in order to establish categories which were put into broad categories reflecting the research questions and, $b$ ) second, by using the computer's word processing program to check that the core content corresponded to the manual categorization. The background data from the questionnaires were categorized according to the themes in the questionnaire.

The analysis resulted in three main categories related to the research questions: a good learning environment for all children, we cope but need somebody to talk to, and working, learning, and growing together.

\section{Results}

\subsection{A Good Learning Environment for All Students}

Based on the teachers' descriptions of the rural school, one overarching category was identified: the rural school as a good learning environment for all students. In all classroom teachers' statements about the learning environment, good relationships and acceptance of diversity were identified. The good relationships were characterized as a warm, caring, and supportive atmosphere in the school. Acceptance of diversity seemed to be a natural approach. Betty's, Carol's, and Anna's statements reflect these views:

Betty: It is a very good atmosphere between the students, and they are tolerant and kind with each other.

Carol: We have many different ages in the classroom. Students understand early that everyone is different and has different needs, not only by age but also because we are good at different things.

Anna: In my class, we worked a lot with the word tolerance and what it means. This could mean that I train students to work with everyone in the class. 
The teachers also mentioned the pedagogical advantages of a rural school. They could help each other and mix student groups in a flexible way. Individual learning needs among students could also be taken into consideration, and learning challenges could be identified at an early stage. According to the teachers, the students benefit from a school with a familiar atmosphere. This is illustrated by statements by Carol and Anna.

Carol: I think some students at our school need less support and educational adaptations than they would in a larger school.

Anna: It is good for students with SEN to attend a small school. Here are a few adults that they quickly get to know well.

The rural school's ability to adapt to new professional challenges was also observed in the teachers' statements. This ability can be exemplified by the way school B received a large number of students with a refugee or immigrant background. The classroom teacher and the special educator regarded the new students as a resource and claimed that the school had developed better teaching strategies that suited all children.

Although the advantages seemed to outweigh the disadvantages in the teachers' descriptions, the lack of resources regarding SEN in rural schools affected the teachers' work. The challenge was that some students needed specific resources that were not available in the rural school. This lack of expertise was evident in school B, and classroom teacher Betty stated, "A speech therapist is not available in the municipality right now, which places greater demands on the classroom teacher. As a consequence, the pupil in question does not receive the right training."

\subsection{We Cope but Need Somebody to Talk To}

When the teachers' statements about consultation as a teacher support strategy were analyzed, one overarching category was found: We cope, but need somebody to talk to. All three classroom teachers had access to a special educator who was placed in the municipality center. They had chosen different strategies in order to bridge the distance between the school and the special educational expertise. In schools A and B, special educators Eve and Fanny visited their respective schools when necessary, but in the mountain school (school C), Carol and the special educator Diana had chosen another strategy. They used information and communications technology (ICT) for consultation because of the distance. They also e-mailed and telephoned frequently.

The classroom teachers are responsible for special needs education in their schools and the classroom teachers preferred this system and had the opportunity to contact the special educator when they experienced a need for consultation. The need was usually expressed as a concern for the students with SEN they taught in their classes. The teachers wanted to discuss the students' learning situation and what they could do in order to facilitate and improve the students' socio-emotional development and academic performance. This is illustrated by an 
excerpt from the consultation session between special educator Eve and classroom teacher Betty:

Eve: You are worried about how he will fix that taking in knowledge.

Betty: He is willing to cooperate, but I am still concerned about his knowledge, especially in math. Can we talk about good material in math?

However, it seems that the teachers do not primarily ask for direct advice; instead, they seek support for their own pedagogical ideas and confirmation that they are on the right track. Although they seem confident in dealing with students with SEN, they clearly appreciate having a special educator to discuss with. Carol expressed the need for an experienced colleague very clearly: "I am the only teacher in the classroom, and then I need someone to talk to about these pedagogical issues. I need it."

Direct advice had been a more salient feature in the past when the teachers were beginning teachers. Carol, who has long experience working at a rural school, described how the function of consultation has changed over the years:

Carol: Almost 20 years ago, when I was a new classroom teacher at a rural school, the consultation strategy was more specific. In the past, you showed me how I could do in the classroom. And you said if you do like this or you think like that, it will be fine. Today, it is different. You (the special educator) are my sounding board.

Sharing of best practices and collaboration between the classroom teachers and special educators was a prominent theme in the consultation sessions. The teachers described what solutions they had found to challenges they had encountered when teaching students with SEN in their classes. This is exemplified in conversations at schools $\mathrm{C}$ and $\mathrm{B}$. The teachers and the special educators are discussing students with medical diagnoses:

Diana: With the diagnosis follows a short working memory. Therefore, he needs brief instructions and short study sessions.

Carol: Yes, thank you for reminding me. Also, I use special devices and tools for him, a tablet with headphones, a Daisy player, and different colors in the lesson plan for different days. We have had the same system for all students, it is not only for him, and there have been other students who have had color-coded days. All children learn when they see that there is a system for everyone whether you can read or not.

Diana: I do think that it is good for all. 
Also in the conversation between Betty and Eve, the sharing of best practices was evident:

Betty: I have developed and taught the students that each letter has a movement and a sound, for example, ssss [Betty shows a movement] means a snake. And so on. I have used it for all students throughout the first year, and he [student with diagnosis] has managed to learn to read.

Eve: You are so good at finding innovative educational solutions. I also learn from you.

\subsection{Working, Learning, and Growing Together}

The consultation sessions studied were characterized by a professional dialogue between two equal partners who bring their own professional expertise into the discussion. Thus, the overarching theme was named working, learning, and growing together. However, the discussions were structured and followed a certain pattern. The special educators took a professional moderator role in the discussions and acted as consultants asking open and clarifying questions, summarizing what had been discussed and verbalizing decisions taken. It was evident that the special educators used their communication skills in the consultation process. The classroom teachers seemed satisfied with the way the special educators conducted the consultation sessions. Classroom teacher Anna stated:

Anna: It's good. I can rest from the leading role because I am always leading the class. I am obviously the driving force when it comes to the content of the consultation, but Fanny summarizes, asks, and demonstrates what we have come up to, and I think this is one of the most important parts of the session.

Although the special educators had a moderator role in the conversations, the focus was clearly on cooperation, mutual problem solving, and professional collaboration. This focus was expressed by classroom teacher Anna: "I think consultation often involves open questions, as a form of cooperation, and it opens up both of us and allows us to extract the most and the best of our skills and experience."

Special educator Eve pointed out that consultation is a kind of help for self-help. By asking the right questions and facilitating reflection, the classroom teachers solve their own professional challenges. From the special educator perspective, the informants from School B highlighted how the consulting process led to insight and understanding of the classroom teacher's own development.

Special educator Eve stated: "Over the years, I have had many consulting sessions, and I think that a consulting conversation is a help for self-help. I think that the classroom teacher through the consulting process should come to understand their own need. The classroom teacher knows the children, and I do not." 
Distributed expertise or professional knowledge exchange was a distinguished feature in the consultation sessions. The classroom teachers and the special educators shared adequate professional experiences and engaged in a professional dialogue. Both teaching professionals learned from each other and valued each other's expertise. New knowledge was created in the dialogues between the classroom teachers and the special educators. This ability to cross professional boundaries is exemplified by special educator Eve.

Eve: "I also get a lot of good advice when the classroom teacher shares her experiences with me. Her experiences give me new perspectives. I see consultation as a collective work when I get to take part of the classroom teacher's experiences and advice to develop my profession."

The collaborative consultation sessions were characterized by a joint intention to solve professional challenges. The special educators and the classroom teachers used their relational skills in order to learn from each other and to actively find solutions to challenges they met in their daily work.

\section{Discussion}

The overarching aim of the article was to shed light on how the expertise of special educators can be utilized in order to support the professional development of teachers who work in rural schools characterized by student diversity. In order to meet this aim we formulated following research questions: (1) How do teachers describe the rural school as a context for consultation? (2) How is consultation perceived as a teacher support strategy in rural schools? (3) What strategies in consultation between teachers and special educators appear?

The schools in this study shared common characteristics of rural schools, such as long distances to municipality centers, a low number of students and teachers, multi-grade classrooms, student diversity, and a lack of support staff. Yet only one of the schools could be characterized as inherently rural (cf. Coladarci, 2007). We approached our research field from three perspectives: the rural school context, consultation as teacher support, and strategies in consultation. Our assumption was that school consultation could be beneficial to teachers who work in rural schools that are characterized by student diversity and a lack of support services.

The rural schools in this study were characterized by caring and supportive relationships, high acceptance of diversity, and the ability to find solutions to professional challenges related to students with SEN. This result is in line with previous research on rural schools and their relationship with the surrounding community (Dowling, 2009; Monk, 2007; Pettersson et al., 2016). It seems that the teachers create a favorable learning environment for all students, regardless of ability or background. One reason for this pedagogical creativity could be that rural teachers, especially those who have very few or no colleagues, turn into jacks-of-all-trades (Kuhl et al., 2014). Other reasons might be the family-like atmosphere of the rural school and good relationships with the surrounding community (Kalaoja \& Pietarinen, 2009; Karlberg-Granlund, 2009). The findings indicate that the favorable learning 
environment can compensate for shortcomings, but only to some extent. The lack of regular special educational expertise and specific resources was a concern, which has been reported in earlier studies (Pettersson et al., 2016; Tuters, 2015). Consultation provided by a special educator can mitigate the negative consequences that the lack of expertise in special education can cause (Berry et al., 2011; Pettersson et al., 2016). However, the schools need to find solutions to bridge the distance between the rural schools and the special education expertise based in municipality centers. The use of ICT for consultation seems to be an option but requires a developed infrastructure for distance-bridging technology, such as video conference systems and mobile broadband.

The consultation provided by the special educators was perceived as a support strategy that promotes the classroom teachers' professional skills in teaching students with SEN. The special educators acted as qualified dialogue partners in accordance with the mandate stated in the policy documents (cf. SFS, 2011, p. 186; Sundqvist et al., 2014) but focused on professional collaboration more than on reflection and advice. The findings show that the classroom teachers possess pedagogical skills that enable the teachers to handle professional challenges related to students with SEN, but the teachers seem to need support and confirmation for pedagogical ideas they had planned, implemented, and evaluated in their classrooms. The focus on collaboration is certainly not unique to rural schools. However, based on the findings, it can be assumed that the lack of regular special education expertise promotes professional learning among classroom teachers. The teachers learn how to handle challenges caused by student diversity. The fact that the function of consultation has changed from advice to collaboration over the years supports this assumption.

Although the classroom teachers in this study seemed to cope with the situation, it was evident that they appreciated the support they could get from the special educator. In addition, previous studies of rural schools have shown that regular and meaningful support is crucial for well-being and for retention among rural teachers (c.f. Pettersson et al., 2016; Tuters, 2015).

The consultation conversations between the classroom teachers and the special educators were characterized by professional exchanges. The dialogue partners shared best practices and solved professional challenges together in what can be characterized as knowledge-creating dialogues (cf. von Ahlefeld Nisser, 2008). These knowledge-creating dialogues seem to develop into professional dialogues, carried out in an atmosphere of mutual trust and respect for each other's professional expertise. The classroom teachers brought into the conversations their unique experience of being rural teachers and their thorough knowledge of the individual students' learning needs, while the special educators contributed expertise about specific methods for improving the learning situation for students with SEN and in the long run for all students in the school. This was an act of relational agency (cf. Edwards, 2005; Edwards et al., 2010; Nowotny, 2003). Through this collective collaborative process, the teachers found common solutions and gained new knowledge together, presumably achieving a broader understanding of the phenomenon compared to the knowledge and understanding one could have achieved (cf. Edwards, 2005; Edwards et al., 2010). 
This focus on professional collaboration seems to demonstrate increased readiness to work across professional borders. The classroom teachers and the special educators expand their professional knowledge in collaborative consultation. The findings indicate that the teaching professionals' cooperative conversations can create good opportunities for professional development. Since earlier studies on rural schools have reported a lack of professional development opportunities (c.f. Berry, Petrin, Gravelle \& Farmer, 2011; Pettersson et al., 2016), school consultation that emphasizes collaboration can be used as a tool for professional development for teachers in rural schools.

Warm and caring relationships, adequate teacher support, and professional collaboration between colleagues can contribute to a truly inclusive learning environment in rural schools where all students have the possibility to learn and develop according to their potential.

\section{Acknowledgements}

My Ph.d. study is funded by Department of Education, Umeå University, Sweden. I gratefully acknowledge the financial support from the Department of Education, which made it possible to get access to the research field and to write this article.

\section{References}

Åberg-Bengtsson, L. (2009). The smaller the better? A review of research on small rural schools in Sweden. International Journal of Educational Research, 48(2), 100-108. http://dx.doi.org/10.1016/j.ijer.2009.02.007

Autti, O., \& Hyry-Beihammer, E. K. (2014). School closures in rural Finnish communities. Journal of Research in Rural Education, 29(1), 1-17. Retrieved from http://jrre.psu.edu/ articles/29-1.pdf

Bæck, U.-D. K. (2015). Rural location and academic success-Remarks on research, contextualisation and methodology. Scandinavian Journal of Educational Research. http://dx.doi.org/10.1080/00313831.2015.1024163

Bagley, C., \& Hillyard, S. (2011). Village schools in England: At the heart of their community? Australian Journal of Education, 55, 37-49.

Barley, Z. A., \& Beesly, A. D. (2007). Rural school success: What can we learn? Journal of Research in Rural Education, 22(1). Retrieved from http://jrre.psu.edu/articles/22- 1.pdf

Berry, A. B. (2012). The relationship of perceived support to satisfaction and commitment for special education teachers in rural areas. Rural Special Education Quarterly, 31(1), 3-14.

Berry, A., Petrin, R., Gravelle, M., \& Farmer, T. (2011). Issues in special education teacher recruitment, retention and professional development: Considerations in supporting rural teachers. Rural Special Education Quarterly, 30, 3-11.

Bladini, K. (2004). Handledning som verktyg och rum för reflektion. En studie av specialpedagogers handledningssamtal [Guidance tools and space for reflection. A study of special educators consulting] (Doctoral thesis, Karlstad University, Sweden). Retrieved from 
http://www.diva-portal.org/smash/get/diva2:5804/FULLTEXT01.pdf

Castro, A. J., Kelly, J., \& Shih, M. (2010). Resilience strategies for new teachers in high-needs areas. Teaching and Teacher Education, 26, 622-629. http://dx.doi.org/10.1016/ j.tate.2009.09.010

Cedering, M. (2016). Konsekvenser av skolnedläggningar. En studie av barns och barnfamiljers vardagsliv $i$ samband med skolnedläggningar $i$ Ydre kommun [The consequences of school closures. A study of children and families everyday in connection with school closures in Ydre] (Doctoral thesis, Uppsala University, Sweden). Retrieved from http://www.diva-portal.org/smash/get/diva2:883424/FULLTEXT01.pdf

Coladarci, T. (2007). Improving the yield of rural education research: An editor's swan song. Journal of Research in Rural Education, 22(3). Retrieved from http://jrre.psu.edu/articles/ 22-3.pdf

County Administrative Board. (2015). Västerbottens län - en beskrivning [Västerbotten County - A description. County Administrative Board]. Retrieved from http://www.lansstyrelsen.se/vasterbotten/SiteCollectionDocuments/Sv/Publikationer/2004/L \%C3\%A4nstransportplan\%202004-2015\%20-\%20kapitel\%204.pdf

Dowling, J. (2009). Changes and challenges: Key issues for Scottish rural schools and communities. International Journal of Educational Research, 48, 129-139. http://dx.doi.org/10.1016/j.ijer.2009.02.005

Edwards, A. (2005). Relational agency: Learning to be a resourceful practitioner. International Journal of Educational Research, 43(3), 168-182. http://dx.doi.org/ 10.1016/j.ijer.2006.06.010

Edwards, A., Daniels, H., Gallagher, T., Leadbetter, J., \& Warmington, P. (2009). Professional learning for inter-professional collaboration. In A. Edwards, H. Daniels, T. Gallagher, J. Leadbetter, \& P. Warmington (Eds.), Improving interprofessional collaborations: Learning to do multi-agency work (pp. 21-42). London: Routledge.

Edwards, A., Lunt, I., \& Stamou, E. (2010). Inter-professional work and expertise: New roles at the boundaries of schools. British Educational Research Journal, 36(1), 27-45.

Egelund, N., \& Laustsen, H. (2006). School closure: What are the consequences for a local society? Nordic Journal of Educational Research, 50(4), 429-439. http://dx.doi.org/10.1080/ 00313830600823787

Erchul, W. P., \& Sheridan, S. M. (2014). Overview. The state of scientific research in school consultation. In W. P. Erchul, \& S. M. Sheridan (Eds.), Handbook of research in school consultation (pp. 3-17). New York, NY: Erlbaum.

Government Offices of Sweden. (2010). Den nya skollagen - för kunskap, valfrihet och trygghet [The new Education Act - for knowledge, freedom of choice and security]. Stockholm, Sweden: Government Offices of Sweden. 
Graneheim, U., \& Lundman, B. (2004). Qualitative content analysis in nursing research: Concepts, procedures and measures to achieve trustworthiness. Nurse Education Today, 24, 105-112. http://dx.doi.org/10.1016/j.nedt.2003.10.001

Hargreaves, L. M. (2009). Respect and responsibility: Review of research on small rural schools in England. International Journal of Educational Research, 48, 117-128. http://dx.doi.org/10.1016/j.ijer.2009.02.004

Hargreaves, L., Kvalsund, R., \& Galton, M. (2009). Reviews of research on rural schools and their communities in British and Nordic countries: Analytical perspectives and cultural meaning. International Journal of Educational Research, 48, 80-88. http://dx.doi.org/10. 1016/j.ijer.2009.02.001

Howley, C. (2004). A critical introduction to useful works about rural life and education. Journal of Education Finance, 29(1), 257-272.

Howley, C., \& Howley, A. (2014). Making sense of rural educational research: Art, transgression, and other acts of terror. In S. White \& M. Corbett (Eds.), Doing educational research in rural settings: Methodological issues, international perspectives and practical solutions (pp. 7-25). New York, NY: Routledge.

Idol, L. (2006). Toward inclusion of special education. Students in general education. A program evaluation of eight schools. Remedial and Special Education, 27(2), 77-94.

Jarzabkowski, L. (2003). Teacher collegiality in a remote Australian school. Journal of Research in Rural Education, 18(3), 139-144.

Kalaoja, E., \& Pietarinen, J. (2009). Small rural primary schools in Finland: A pedagogically valuable part of the school network. International Journal of Educational Research, 48, 109116. http://dx.doi.org/10.1016/j.ijer.2009.02.003

Karlberg-Granlund, G. (2009). Att förstå det stora i det lilla: byskolan som pedagogik, kultur och struktur [To understand the greatness in small things: The rural school as education, culture and structure] (Doctoral thesis, Åbo Akademi University, Åbo, Finland). Retrieved from http://www.doria.fi/bitstream/handle/10024/43691/KarlbergGunilla.pdf?sequence=1

Karlberg-Granlund, G. (2011). Coping with the threat of closure in a small Finnish village school. Australian Journal of Education, 55(1), 62-71.

Kearns, R. A., Lewis, N., McCreanor, T., \& Witten, K. (2009). The status quo is not an option: Community impacts of school closure in South Taranaki, New Zealand. Journal of Rural Studies, 25, 131-140. http://dx.doi.org/10.1016/j.jrurstud.2008.08.002

Kuhl, S., Pagliano, P., \& Boon, H. (2014). In the too hard basket: Issues faced by 20 rural Australian teachers when students with disabilities are included in their secondary classes. International Journal of Inclusive Education, 19, 697-709. http://dx.doi.org/10.1080/13603 116.2014.964570

Lind, T., \& Stjernström, O. (2015). Organizational challenges for schools in rural 
municipalities: Cross-national comparisons in a Nordic context. Journal of Research in Rural Education, 30(6), 1-14.

Lindqvist, G. (2013). Who should do what to whom. Occupational groups' views on special needs. (Doctoral thesis, Jönköping University, School of Education and Communication, Sweden. Retrieved from http://www.diva-portal.org/smash/get/diva2:665062/FULLTE XT01.pdf

Malloy, W. W., \& Allen, T. (2007). Teacher retention in a teacher resiliency-building rural school. The Rural Educator, 28(2), 19-27.

McHenry-Sorber, E., \& Schafft, K. A. (2014). Make my day, shoot a teacher: Tactics of inclusion and exclusion, and the contestation of community in a rural school-community conflict. International Journal of Inclusive Education, 19, 733-747. http://dx.doi.org/ $10.1080 / 13603116.2014 .964571$

Monk, D. H. (2007). Recruiting and retaining high-quality teachers in rural areas. The Future of Children, 17(1), 155-174. Retrieved from http://www.jstor.org/stable/4150024?seq=1\&cid =pdf-reference\#references_tab_contents

Murdoch, J., Lowe, P., Ward, N., \& Marsden, T. (2003). The differentiated countryside. London, England: Routledge.

Nowotny, H. (2003). Dilemma of expertise. Democratising expertise and socially robust knowledge. Science and Public Policy, 30, 151-156.

Pettersson, G., Näsström, G. (submitted, 2015). Rektor i kläm mellan uppdrag och förutsättningar - specialpedagogisk verksamhet i små svenska glesbygdsskolor. [Principal squeezed between mission and conditions - special needs education in Swedish small rural schools]. Nordisk Tidskrift för Allmän Didaktik. [Nordic Journal of General Education].

Pettersson, G., Ström, K., \& Johansen, J. B. (2016). Teachers' views on support in small rural schools for students with special educational needs. Nordic Studies in Education, 36, 20-37. http://dx.doi.org/10.18261/issn.1891-5949-2016-01-03

Pini, B., Carrington, S., \& Adie, L. (2014). Schooling elsewhere: Rurality, inclusion and education. International Journal of Inclusive Education. 1-8. http://dx.doi.org/10.1080/ 13603116.2014.964489

Pugach, M. C., \& Johnson, L. J. (1995). Collaborative practitioners: Collaborative schools. Denver, CO: Love.

Sahlin, B. (2005). Utmaning och omtanke. En analys av handledning som en utvidgad specialpedagogisk funktion i skolan med utgångspunkt i tio pionjärers berättelser [Challenge and consideration. An analysis of guidance as an extended special educational function of the school on the basis of ten pioneers' stories] (Doctoral thesis, Stockholm University, Institute of Education, Sweden). Retrieved from http://www.diva-portal.org/smash/get/diva2:192375/ FULLTEXT01.pdf 
Schafft, K. A., \& Youngblood Jackson, A. (2010). Introduction. In Schafft, K. A., \& Youngblood Jackson, A. (Eds.), Rural education for the twenty-first century: Identity, place and community in a globalizing world. University Park: Pennsylvania University Press.

SFS. (2011). Svensk författningssamling [Swedish code of statutes]. Retrieved from https://www.notisum.se/rnp/sls/sfs/20110186.pdf/July

SKOLFS. (2014). Skolverkets allmänna råd om arbete med extra anpassningar, särskilt stöd och åtgärdsprogram [National Agency general guidelines on working with additional adjustments, special support and action]. The Swedish National Agency for Education. Retrieved from http://www.skolverket.se/regelverk/skolfs/skolfs?_xurl_http $\% 3 \mathrm{~A} \% 2 \mathrm{~F} \% 2$ Fwww5.skolverket.se $\% 2$ Fwtpub\%2Fws $\% 2$ Fskolfs $\% 2$ Fwpubext $\% 2 F f s \% 2 F R e c o r d \% 3 F k \% 3 D$ 2903

Solstad, K. J. (2009). Bygdeskolen i velstands-Noreg: Om endringar i skolestrukturen $i$ spreittbygde kommunar i perioden 1980-2005 [The district school in prosperous Norway: on changes in school structure in sparsely populated municipalities in the period 19802005]. Valseth, Norway: Oplanske Bokforlag.

Sundqvist, C., \& Ström, K. (2015). Special education teachers as consultants: Perspectives of Finnish teachers. Journal of Educational and Psychological Consultation, 25(4), 314-338. http://dx.doi.org/10.1080/10474412.2014.948683

Sundqvist, C., von Ahlefeld Nisser, D., \& Ström, K. (2014). Consultation in special needs education in Sweden and Finland: A comparative approach. European Journal of Special Needs Education, 29, 297-312. http://dx.doi.org/10.1080/08856257.2014.908022

Tuters, S. (2015). Conceptualising diversity in a rural school. International Journal of Inclusive Education, 19, 685-696. http://dx.doi.org/10.1080/13603116.2014.964573

von Ahlefeld Nisser, D. (2014). Specialpedagogers och speciallärares olika roller och uppdrag [Specialpedagogers and special teachers' roles and missions]. Nordic Studies in Education, 34, 246-264.

von Ahlefeld Nisser, S. (2009). Vad kommunikation vill säga. En iscensättande studie om specialpedagogers yrkesroll och kunskapande samtal [What is communication?

A staging study on special educators' professional role and knowledge talks] (Doctoral thesis, Stockholm University, Sweden). Retrieved from http://www.diva-portal.org/smash/get/ diva2:523384/FULLTEXT01.pdf

Woods, M. (2006). Redefining the "rural question": The new "politics of the rural" and social policy. Social Policy \& Administration, 40(6), 579-595.

\section{Copyright Disclaimer}

Copyright reserved by the author(s).

This article is an open-access article distributed under the terms and conditions of the Creative Commons Attribution license (http://creativecommons.org/licenses/by/3.0/). 